\title{
Overview of fire curtains in construction
}

\author{
Oleg Nedryshkin ${ }^{1 *}$, Marina Gravit ${ }^{2}$, Anton Lyapin $^{3}$, Viktor Voronin $^{4}$ \\ ${ }^{1,2}$ Peter the Great St. Petersburg Polytechnic University, 195251, 29, Politekhnicheskaya st., Russia \\ 2,3 Moscow State University of Civil Engineering, 129337, 26, Yaroslavskoye Shosse, Moscow, \\ Russia
}

\begin{abstract}
A fire curtain is use where, if there is a fire, it is necessary to create a temporary barrier within an opening, which seals off the area on fire. The curtain descends and prevents any fire and smoke from spreading from one area to another. It also allows people access to protected escape routes without any loss of fire resistance. The paper aims to presents the results of analysis of the scientific literature on the subject of fire curtains.
\end{abstract}

\section{Introduction}

In modern scientific, regulatory, and legal and technical literature, the term "fire curtains" refers to the structure, preventing the fire from spreading through the building and its hazards (heat flow, smoke, $\mathrm{CO}, \mathrm{CO} 2, \mathrm{HCL}$ et. al.). Fire curtains also known by the terms "fire-retardant curtains," "Smoke curtains", "fire and smoke curtains". Under these terms, in all their diversity we mean the curtains to prevent the spread of fire hazards.

Performing the function of a fire barrier, curtains only when necessary (in case of fire) cut off the individual volumes and escape routes of the total building space. For example, fire curtains with degree of protection EI 60,120 or 180 do not allow the fire to spread to the neighboring room. Fire curtains are a new type of fire protection. They can be used not only in the design and construction of new buildings, but also in the reconstruction of existing buildings [1].

\section{Methods}

Fire curtains are certified in accordance with the BS EN 949, BS EN 1634-3, BS 5234-2, BS EN 1363-2, BS EN 1634-1, BS EN 1363-1, BS EN 12605, BS EN 13501-2. In Russia, curtains are certified in accordance with the Technical regulations for fire safety requirements [2], National standards of Russia 30247.0-94, 30247.1-94, 53305-2009, $53307-2009[3-6]$.

\section{Results}

The aim of fire protection system's usage is to maintain the temperature of the building component (structural steel element, electrical installation) bellow the critical temperature during fire but also is intended to contain a fire in the origin fire compartment for a limited period of time. In the paper [7] the passive fire protection material solutions were described 
and their action mode explained. The paper [8] presents findings from comprehensive research on influence of fire barrier on fire performance of External Thermal Insulation Composite System - ETICS with combustible thermal insulation. To confirm findings, tests on identical ETICS systems were conducted in March 2014 and May 2014.

The authors [9] proposed a new way, which consists in the enclosure securable object retardant screen, in which the porous structure materials at creation environment vapor of coolant is shown a continuous physical effect of evaporative cooling.

The paper [10] describes how to use fire-screens and curtains, as part of an automatic fire protection system, in particular in the high-rise warehouse with shelves. Described in detail the action of fire barriers in case of fire in the warehouses. Table 1 provides information of fire curtains.

Table 1. Comparison of fabricators curtains.

\begin{tabular}{|c|c|c|c|c|c|}
\hline № & $\begin{array}{c}\text { Fabricator } \\
\text { (brand) }\end{array}$ & $\begin{array}{c}\text { Tested } \\
\text { according to }\end{array}$ & Fire resistance & $\begin{array}{c}\text { Manufacturer } \\
\text { country }\end{array}$ & Official site \\
\hline 1 & $\begin{array}{l}\text { Stöbich } \\
\text { Brandschutz } \\
\text { Gmbh }\end{array}$ & $\begin{array}{l}\text { EN 1634-1 } \\
\text { EN 13501-2 }\end{array}$ & $\begin{array}{l}\text { EI } 90 \\
\text { EI } 120 \\
\text { EI } 180\end{array}$ & Germany & stoebich.com \\
\hline 2 & Fogo & $\begin{array}{l}\text { EN 1634-1 } \\
\text { EN 13501-2 }\end{array}$ & $\begin{array}{l}\text { E } 60 \\
\text { E } 120 \\
\text { EW } 120\end{array}$ & Lithuania & fogo.lt \\
\hline 3 & FireScreen & EN13501-1 & E 30 & Netherlands & $\begin{array}{c}\text { firescreen.co } \\
\mathrm{m}\end{array}$ \\
\hline 4 & Firetechnics & $\begin{array}{l}\text { National } \\
\text { standards of } \\
\text { Russia [3-6] }\end{array}$ & $\begin{array}{l}\text { EI } 60 \\
\text { EI } 180\end{array}$ & Russia & fire-tec.ru \\
\hline 5 & Pulsar Doors & $\begin{array}{l}\text { National } \\
\text { standards of } \\
\text { Russia [3-6] }\end{array}$ & $\begin{array}{l}\text { EI } 30 \\
\text { EI } 90\end{array}$ & Russia & $\begin{array}{c}\text { pulsardoors.r } \\
\mathrm{u}\end{array}$ \\
\hline 6 & Door Master & $\begin{array}{l}\text { National } \\
\text { standards of } \\
\text { Russia [3 }-6]\end{array}$ & EI 60 & Russia & doormaster.ru \\
\hline 7 & Bach & $\begin{array}{l}\text { EN 1634-1 } \\
\text { EN 1634-3 }\end{array}$ & $\begin{array}{l}\text { EI } 120 \\
\text { EI } 180 \\
\end{array}$ & Spain & bach-sl.com \\
\hline 8 & Naffco & $\begin{array}{l}\text { NFPA 252, UL } \\
10 \mathrm{D}, \\
\text { FM Global, BSI, } \\
\text { EN. }\end{array}$ & Optional & $\begin{array}{l}\text { United Arab } \\
\text { Emirates }\end{array}$ & naffco.com \\
\hline 9 & $\begin{array}{l}\text { Bradley Lomas } \\
\text { Electrolok }\end{array}$ & $\begin{array}{l}\text { EN 1634-1 } \\
\text { EN 13501-2 } \\
\text { et.al. }\end{array}$ & $\begin{array}{l}\text { EI } 120 \\
\text { EW } 120\end{array}$ & United Kingdom & $\begin{array}{c}\text { ble- } \\
\text { smokeandfire } \\
\text { curtains.com }\end{array}$ \\
\hline 10 & Coopersfire & $\begin{array}{l}\text { BS EN 1634- } \\
1: 2008\end{array}$ & $\begin{array}{l}\text { E } 120 \\
\text { E } 180 \\
\text { EW } 60 \\
\text { EI } 120 \\
\end{array}$ & United Kingdom & $\begin{array}{c}\text { coopersfire.c } \\
\text { om }\end{array}$ \\
\hline 11 & Colt Group & $\begin{array}{l}\text { EN 1634-1 } \\
\text { EN 13501-2 }\end{array}$ & $\begin{array}{l}\text { E } 60 \\
\text { E } 180\end{array}$ & United Kingdom & $\begin{array}{c}\text { coltgroup.co } \\
\text { m }\end{array}$ \\
\hline 12 & FireCurtains & $\begin{array}{l}\text { EN 1634-1 } \\
\text { EN 13501-2 } \\
\end{array}$ & $\begin{array}{l}\text { E } 60 \\
\text { E } 240 \\
\end{array}$ & $\begin{array}{l}\text { United Kingdom, } \\
\text { India, Poland }\end{array}$ & $\begin{array}{c}\text { firecurtainsltd } \\
\text {.com }\end{array}$ \\
\hline 13 & Smoke Guard & $\begin{array}{l}\text { NFPA 252, UL } \\
\text { 10D }\end{array}$ & $\begin{array}{l}\text { Fire resistance } \\
\text { up to } 2 \mathrm{hr} \text {. }\end{array}$ & $\begin{array}{c}\text { United State of } \\
\text { America }\end{array}$ & $\begin{array}{c}\text { smokeguard.c } \\
\text { om }\end{array}$ \\
\hline 14 & Newtex & $\begin{array}{l}\text { ASTM D6413, } \\
\text { ASTM E-84, }\end{array}$ & Optional & $\begin{array}{c}\text { United State of } \\
\text { America }\end{array}$ & newtex.com \\
\hline
\end{tabular}


Usually fire curtains are manufactured from a woven glass fibre fabric with stainless steel wire reinforcement. The fabric is coated on each side with silver polyurethane. The complete curtain assembly is rated at $1000^{\circ} \mathrm{C}$ for a period of up to 240 minutes for Integrity (E), and 60 minutes for Irradiation (W), depending on the size of the curtain. Fire curtains are manufactured in many countries. Fire curtains are popular decision on fire safety in construction.

For Russia this is possible is a relatively new solution for fire safety [1]. For example, the company Stöbich Brandschutz GmbH develops and produces fire curtains for 15 years [11].

Figure 1 - example application of fire curtains.
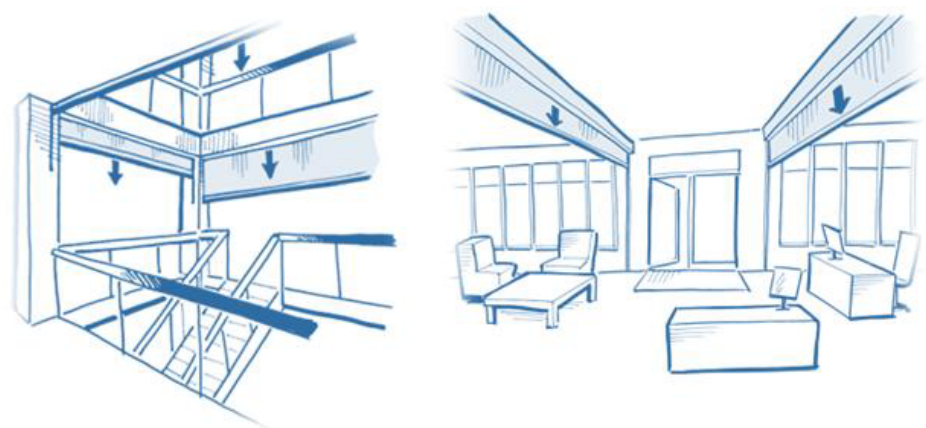

Fig. 1. Example application of fire curtains in construction

Fire curtains are made of silica material and are well suited to prevent the spread of fire hazards in buildings with an atrium. As a demonstration of the spread of fire hazards presented calculation of materials in the GUI FDS PyroSim, Smokeview (figure 2 - 3).

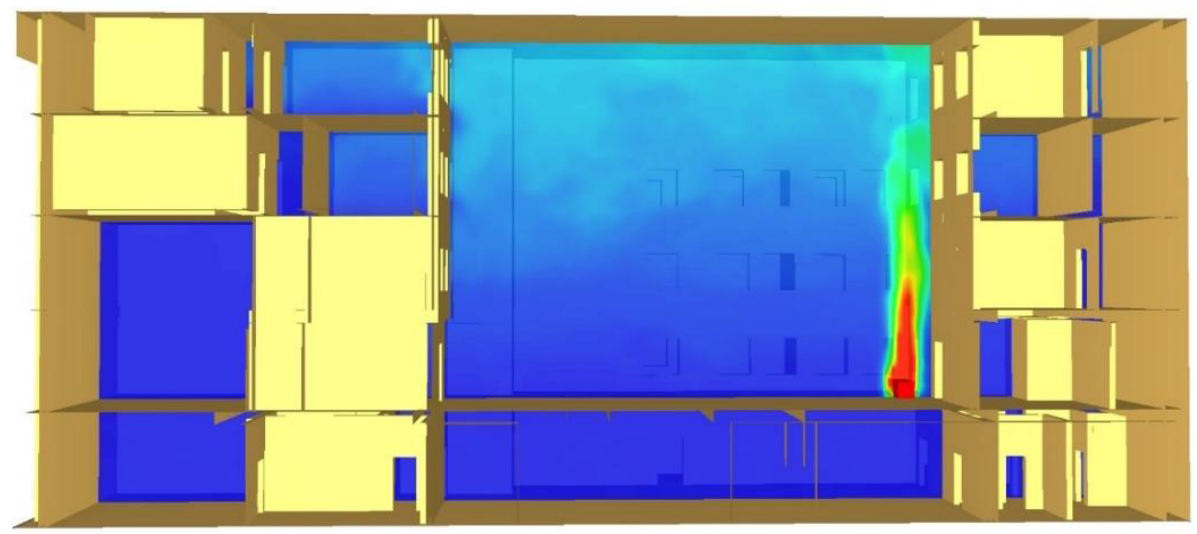

Fig.2. - Distribution of hazardous fire factors elevated temperature 


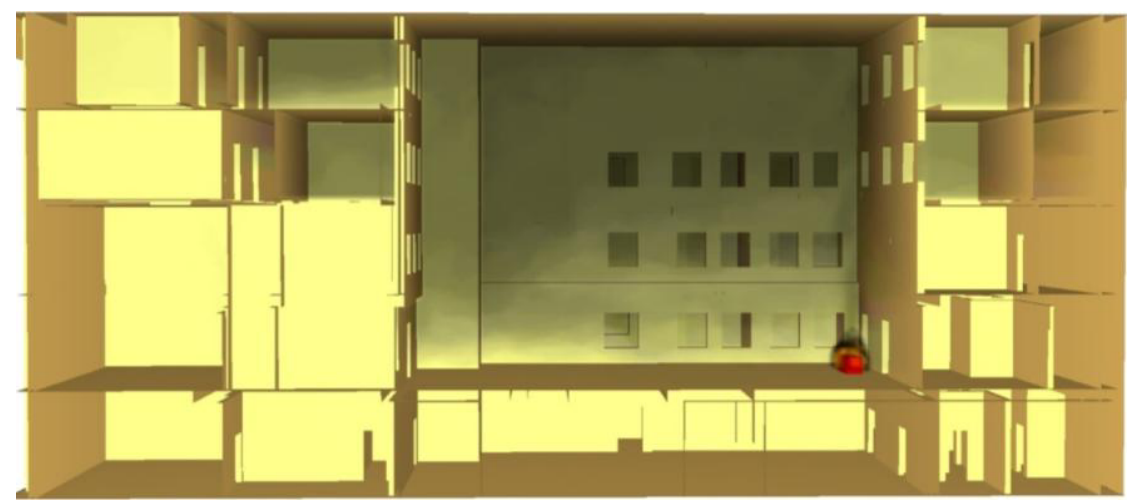

Fig.3. - The spread of fire hazards for the loss of sight

Figure 4 demonstrates the fire resistance ability of the fire curtains it is Fire Dynamics Simulator model.
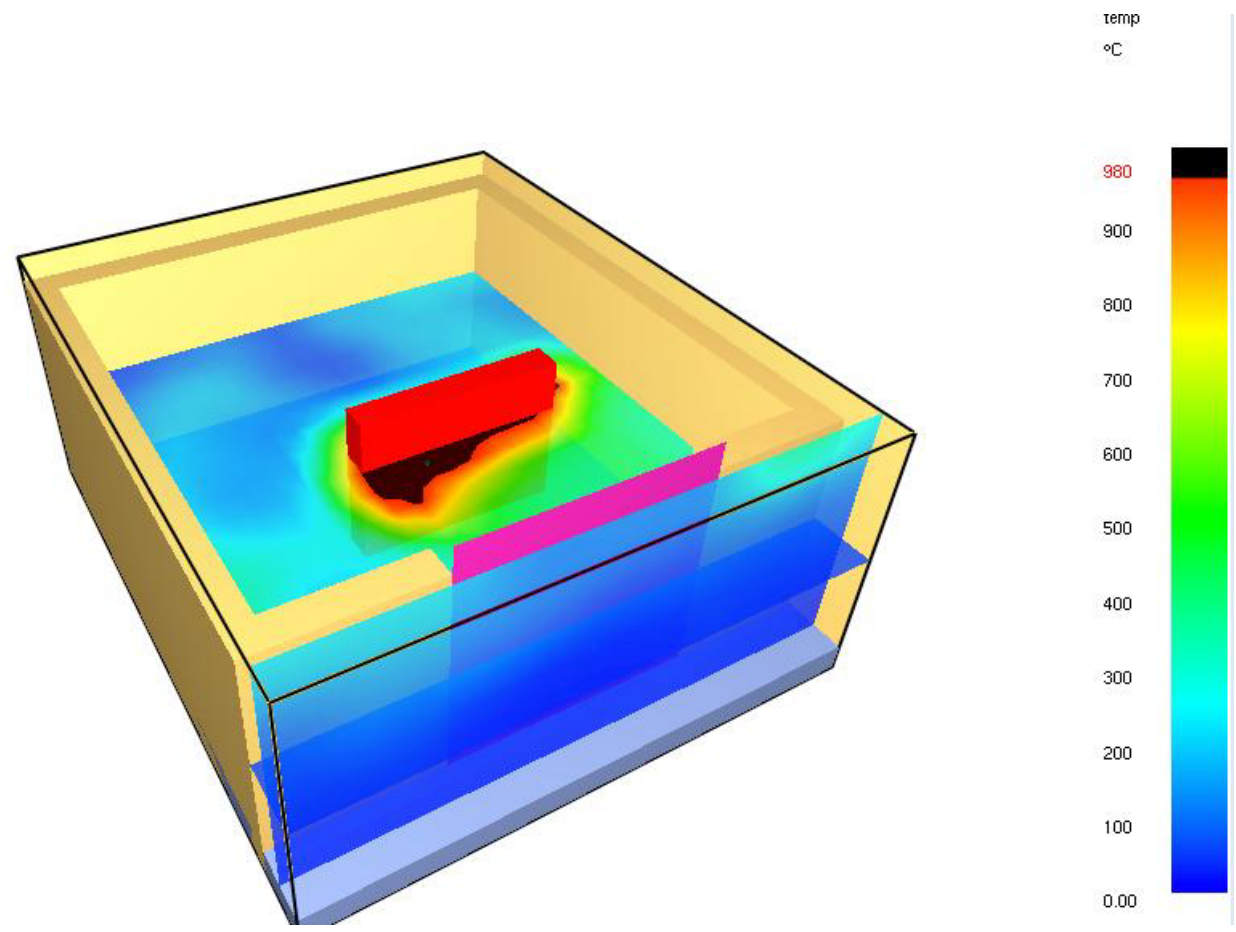

Fig.4. - Fire resistance ability of the fire curtains

\section{CONCLUSION}

If the Fire Curtains do not deploy to their operational position, the fire-engineered design solution would be compromised. However, in the event that other fire protection systems or elements do not function, e.g. due to total power failure, the Fire Curtains in the fireoperational position provide fire separation.

Automatic fire-fighting systems to bring the curtains in the operation have probability of failure of 0.99 . There are systems, which exclude the electro-mechanical components, 
which is a more reliable means.

Fire curtains is a good tool for fire protection in civil engineering. The use of fire curtains allows you to keep the aesthetic appearance of structures. Materials used in fire curtains can be used for fire protection of structures. [12 - 13]

\section{References}

1 A.YA. Korol'chenko, D.P. Getalo. Fire curtains (review). Fire \& Explosion Safety, 4, $56-65$ (2015).

2 Technical regulations for fire safety requirements. Federal Law No. 123 (in red.

Federal Law of 10.07.2012 No. 117). Rossiyskaya gazeta [Russian Newspaper] (2008), No. 163. (rus).

3 National standard of Russia 30247.0-94 Elements of building constructions. Fireresistance test methods. General requirements. Information on http://docs.cntd.ru/document/gost-30247-0-94 (on Russian)

4 National standard of Russia 30247.1-94 Elements of building constructions. Fireresistance test methods. Loadbearing and separating constructions. Information on http://docs.cntd.ru/document/gost-30247-1-94 (on Russian)

5 National standard of Russia 53305-2009 Smoke shields. The test method for the fire resistance. Information on http://docs.cntd.ru/document/1200071868 (on Russian)

6 National standard of Russia 53307-2009 Smoke shields. Elements of building constructions. Fire doors and gates. Fire resistance test method. Information on http://docs.cntd.ru/document/1200071942 (on Russian)

7 K. Mróz, I. Hager, K. Korniejenko. Procedia Engineering 151, 284-291 (2016) DOI: 10.1016/j.proeng.2016.07.388

8 D. Bjegovic, I. Banjad Pecur, B. Messerschmidt, B. Bojan Milovanovic, M. Alagusic. MATEC Web of Conferences 46, 1-11 (2016) DOI: 10.1051/matecconf/20164605006

9 S.V. Zaikin, V.L. Strahov. Vestnik MGSU 4, 107-112 (2009) (on Russian)

10 S. Zharov. Safety algorithm 5, 6-9 (2006)

11 Information from official site Stöbich Brandschutz Gmbh: http://www.stoebich.com/www/webseite_tpl/ws_tpl1.php?webseite_id=11\&sprache_w echseln_get $=1 \&$ menuepunkt_gewaehlt_get $=529$

12 J. Ćetković, M. Knežević, M., Žarković, V. Murgul, N. Vatin, AMM, 638-640, 24652470 (2014)

13 Yong-Qian Zheng, Lin-Hai Han. Fourth International Conference on Advances in Steel Structures 2, 1017-1022 (2005) 